\title{
Study of Internal Waste Dump-Induced Shear Stress Behavior on Pit-Slope
}

\author{
Sugeng Wahyudi ${ }^{*}$, Hideki Shimada1, Takashi Sasaoka ${ }^{1}$, Akihiro Hamanaka1, \\ Tsedendorj Amarsaikhan ${ }^{2}$, Pisith Mao', Tumelo K. M. Dintwe ${ }^{1}$, Dyson Moses ${ }^{1}$ \\ ${ }^{1}$ Department of Earth Resources Engineering, Kyushu University, Fukuoka, Japan \\ ${ }^{2}$ Mining Research and Design Center, Mongolian University of Science and Technology, Sukhbaatar, Mongolia \\ Email: *wahyudi_sugeng@mine.kyushu-u.ac.jp
}

How to cite this paper: Wahyudi, S., Shimada, H., Sasaoka, T., Hamanaka, A., Amarsaikhan, T., Mao, P., Dintwe, T. K. M., \& Moses, D. (2020). Study of Internal Waste Dump-Induced Shear Stress Behavior on Pit-Slope. Journal of Geoscience and Environment Protection, 8, 71-86.

https://doi.org/10.4236/gep.2020.84006

Received: March 5, 2020

Accepted: April 18, 2020

Published: April 21, 2020

Copyright $\odot 2020$ by author(s) and Scientific Research Publishing Inc. This work is licensed under the Creative Commons Attribution International License (CC BY 4.0).

http://creativecommons.org/licenses/by/4.0/

\begin{abstract}
Regardless of beneficial associated with internal waste dump (IWD) method, practices of this method within boundaries of pit-slope have some serious problems on stability issues due to this area is zone of potential failure. This zone is known as dynamic reactive zone which is easy to deform by external force, and inherent dangers of failure posing a threat to slope. Therefore, it is paramount to study the induced shear stress behavior in this zone particularly when IWD method is adopted within this zone. In this paper, a numerical study for investigating IWD-induced shear stress behavior has been carried out using Finite Element Method (FEM) with Strength Reduction approach. Different scenarios as per pit-slope depths, IWD heights and buffer zone lengths have been accounted and simulated using PHASE 2 to understand changes in induced shear stress imposed on the pit-slope. It is found that shear stress imposed on pit slope seems change dramatically with increasing IWD height for case of buffer zone length is less than 100-m-long.
\end{abstract}

\section{Keywords}

Slope Stability, Internal Waste Dump, Shear-Stress, Numerical Simulation

\section{Introduction}

Internal waste dump (IWD) within boundaries of pit-slope is one of solutions to cut waste material hauling cost, particularly when the waste contains low grade valuable mineral which is planned to proceed further in future. However, practices of this method is challenging considering to area within pit-slope boundaries are a potential failure zone (Hustrulid et al., 2013), as illustrated in Figure 1. This zone of potential failure is known as dynamic reactive zone which is easy to 


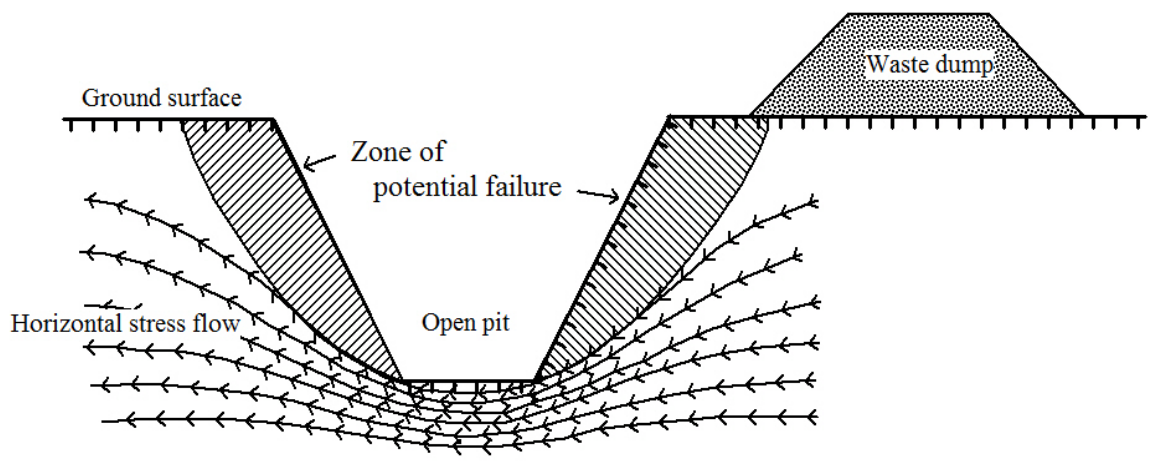

Figure 1. Characteristic of potential failure zone in an open pit (modified from Hustrulid et al., 2013).

deform by external force. Thus, when an IWD material is dumped in this zone, the slope surface will easy to distress, and shear stress imposed on the pit-slope surface will swiftly increase. If this shear stress is not controlled, tensile stressinduced cracks can open with a subsequent reduction in the cohesive and friction forces restraining pit-slope in place. This situation can reduce the effective normal force on potential failure planes. When the depth of pit-slope increases, shear stress on the pit-slope surface will extensive due to increase in load gravity, the extent of this distressed zone will more radical accordingly. This condition brings the shear stress imposed on pit-slope is larger than the strength of the pit-slope, and it can cause the slope failure (Cho \& Song, 2014; Scott et al., 2007). Furthermore, it will get worse when poor blasting practice-induced tension cracks occur in this slope (Khandelwal \& Singh, 2009; Persson et al., 1994; Calder, 1977).

Theoretically, increase in pit-slope depth will be followed by increasing shear stress due to increasing gravity load imposed on the slope. And the pit-slope will be more distressed when an IWD is dumped at top of the pit-slope due to increasing induced shear stress. This shear stress on the pit-slope will decrease when the IWD is moved away from boundaries of the pit-slope. This study investigates shear stress behavior on pit-slope when those three parameters, i.e. pit-slope depth, IWD height and buffer zone length, are changed. In order to investigate and explore shear stress behavior on pit-slope in regards with intercorrelation between pit-slope depth, IWD height and buffer zone length, a study of numerical analysis for IWD-induced shear stress imposed on pit-slope has been carried out using Finite Element Method (FEM) with Strength Reduction approach to understand changes in stress reduction factor (SRF) with variation pitslope depth and IWD height under different buffer zone length.

\section{Modeling Procedure and Parameter Study}

\subsection{Factor of Safety and Strength Reduction Factor}

In numerical simulation, stability of pit-slope is typically expressed with factor of safety i.e. ratio between resisting and driving forces of the rock mass (Wesseloo 
\& Read, 2009). It can also be defined with a ratio between the tangent stress related to the shear strength of rock mass and shear stress induced weight and other factors influencing the rock mass behavior. The equation is generally expressed as follows:

$$
\text { Factor of safety }=\tau_{r} / \tau_{s} \text {. }
$$

where, $\tau_{s}$ is shear stress, while $\tau_{r}$ is maximum shear resistance estimated by Mohr-Coulomb Failure Criterion. This maximum shear resistance can be calculated by equation:

$$
\tau_{r}=c+\sigma \tan \varphi
$$

where, $c$ is cohesion, $\sigma$ is normal stress, $\varphi$ is friction angle.

Considering to a decision-making process of numerical method that leads to a realistic explanation particularly in case of slope design (Rocscience, 2005; Itasca, 2004; Rockfield, 2001), the continuum model of PHASE2 is adopted in this study. The PHASE2 is an extremely versa-tile two-dimensional elastoplastic finite element stress analysis program. One of the major features of this software is the using of shear strength reduction (SSR) method that can be set fully automated and can be used with either Mohr-Coulomb or Hoek-Brown strength parameters (Rocscience, 2005). In slope stability analysis, the SSR technique is used to determine a stress reduction factor (SRF) or factor of safety value that brings a slope to the verge of failure (Hammah et al., 2005). In this study, SRF 1.25 is considered as standard of safety (Wasseloo \& Read, 2009).

Two key parameters that are considered in slope stability analysis are cohesion and angle of friction. A slope is considered unstable in the SSR technique when cohesion and friction angle in the shear strengths of slope successively diminishes until the finite element model does not converge to a solution (Hammah et al., 2005). These conditions are expressed by equations:

$$
\begin{gathered}
c_{\text {mob }}=c / \text { Factor of Safety } . \\
\varphi_{\text {mob }}=\varphi / \text { Factor of Safety } .
\end{gathered}
$$

where, $c_{m o b}$ is mobilized cohesion and $\varphi_{m o b}$ is mobilized friction angle.

\subsection{Study Area Description}

A case from a surface porphyry copper and molybdenum (Mo) deposit mine where IWD is taking place has been considered. This studied mine currently is at level of 240-m-deep. The studied mine has 3 IWD sites where located 50 to 600-m-long from boundaries of pit-slope. Current situation of IWD of the studied mine is illustrated in Figure 2; red line and pink line indicate current and long-term pit designs respectively, while blue line and green line show current and long-term IWD designs respectively. It is seen in this figure that blue line and pink line is crossed. It means the pit slope of long-term pit design will be at right next to IWD in future. Therefore, if the long-term pit and IWD is not 


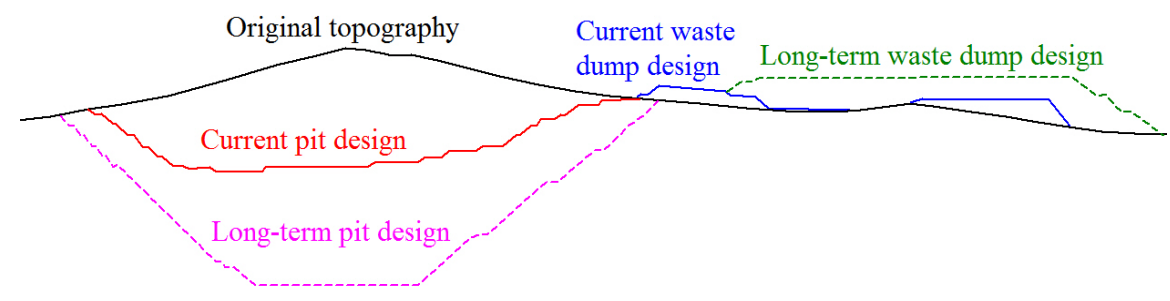

Figure 2. Long-term mine planning of studied mine.

designed well, the pit-slope will be largely distressed by IWD-induced shear stress. Furthermore, if this situation is not properly controlled, slope failure may occur as demonstrated in Figure 3.

In this study, the numerical model was built, and set-up based on actual condition of the studied mine such as: 1) Lithology consists of three main layers i.e. oxidation zone, transition zone and fresh rock; 2) Rock properties of main layers and IWD material; and 3) Current and long-term mine planning.

\subsection{Governing Model}

The numerical modeling of this study is performed by adopting continuum mechanics code PHASE2 which developed by Rocscience. The model geometry is created generally based on actual field geometry of the studied mine. The investigation area is $4-\mathrm{km}$-long and 2-km-wide (Figure 4). To reproduce failure mechanism in an accurate way, fine discretization is considered for the active zone of potential failure. The behavior of the rock mass is simulated by using a constitutive model based on Mohr-Coulomb theory and allows the implementation of strain strength reduction due to embedded planes of weakness.

In the numerical modeling, the selection of parameters is often considered from the most difficult element in the generation of a model due to the high uncertainty in the parameter data-base, in which the geotechnical parameters were conventionally derived from laboratory tests. The tests were conducted for three sample types i.e. oxidation rock sample, transition rock sample and fresh rock sample. The rock properties from the laboratory test are summarized in Table 1.

According to the literatures (Li et al., 2011; Jimenez-Rodriguez \& Sitar, 2007; Low, 2007; Jimenez-Rodriguez et al., 2006), cohesion (c) and friction angle $(\varphi)$ is key parameters in reliability analysis of slope stability. Based on the properties of rock samples given in Table 1, cohesion of IWD rock is weaker than that of the pit-slope rock. Thus, in this study, stability of IWD is also considered besides stability of pit-slope. Moreover, a failure is also possible to occur at the oxidation zone area of the pit-slope due to low rock properties.

In order to investigate the shear stress behavior on safe distance limit of buffer zone for a safe pit-slope and IWD stabilities, the models were simulated for different geometry of pit-slope depth from 240 to 440 -m-deep, IWD height from 0 to 150 -m-high, and buffer zone length from 0 to 200-m-long. The concept of the numerical simulation can be seen in Figure 5. 

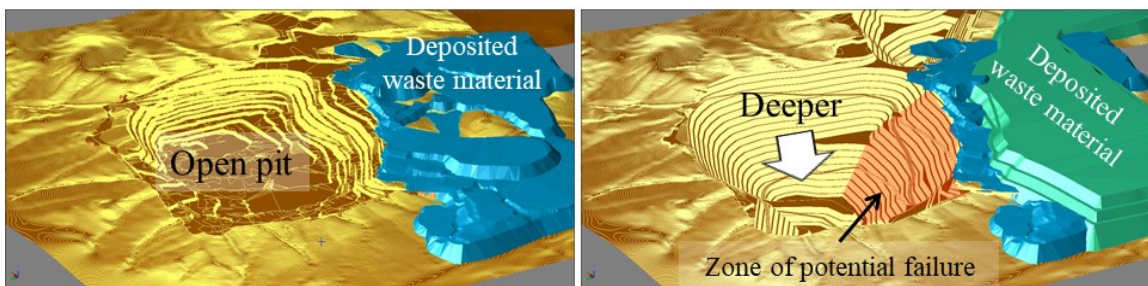

Figure 3. Zone of potential failure due to IWD-induced shear stress on pit-slope.

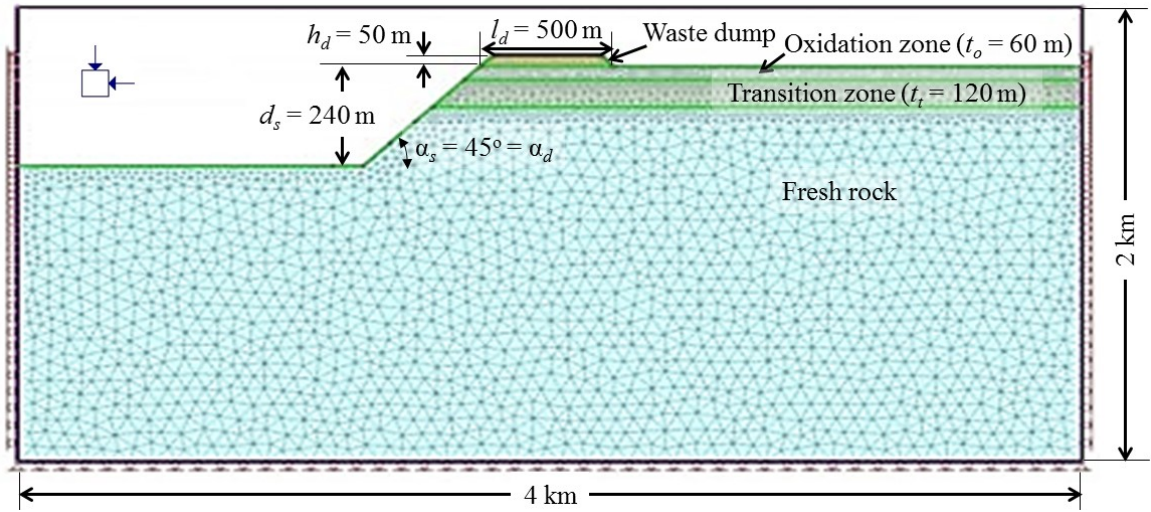

Figure 4. Calculation model.

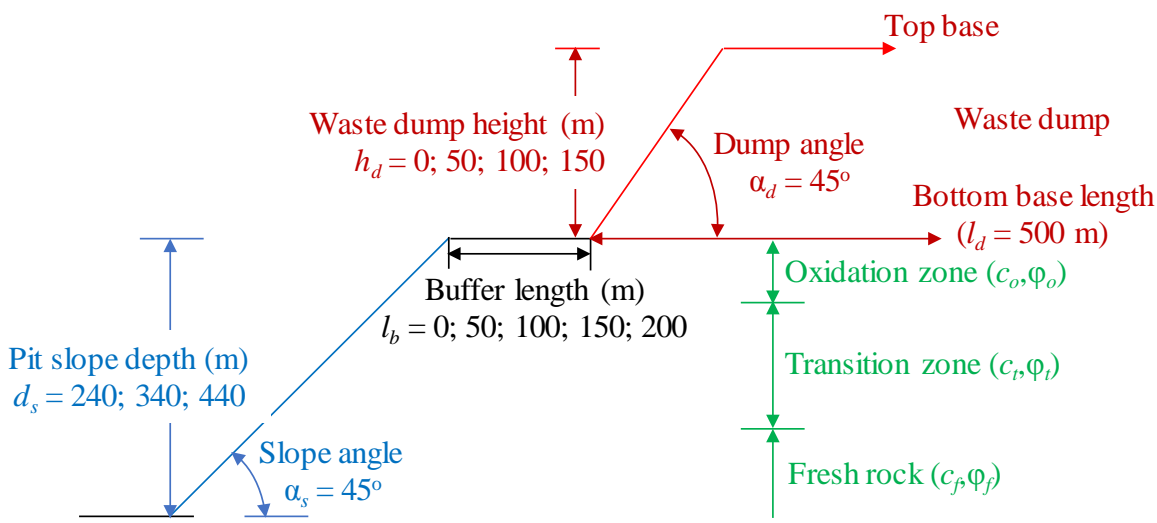

Figure 5. Concept for the numerical simulation: geometry of pit-slope, IWD and buffer zone.

Table 1. Input parameters (rock property).

\begin{tabular}{ccccccc}
\hline Material & $\begin{array}{c}\text { Unit weight, } \\
\mathrm{MN} / \mathrm{m}^{3}\end{array}$ & $\begin{array}{c}\text { Friction } \\
\text { angle, } \\
\text { degree }\end{array}$ & $\begin{array}{c}\text { Cohesion, } \\
\mathrm{MPa}\end{array}$ & $\begin{array}{c}\text { Tensile } \\
\text { strength, } \\
\mathrm{MPa}\end{array}$ & $\begin{array}{c}\text { Young's } \\
\text { modulus, } \\
\mathrm{GPa}\end{array}$ & $\begin{array}{c}\text { Poisson's } \\
\text { ratio }\end{array}$ \\
\hline $\begin{array}{c}\text { Oxidation } \\
\text { material }\end{array}$ & 0.023 & 26.5 & 0.5 & 0.6 & 1.5 & 0.254 \\
$\begin{array}{c}\text { Transition } \\
\text { material }\end{array}$ & 0.026 & 32.4 & 0.6 & 0.8 & 2 & 0.254 \\
$\begin{array}{c}\text { Fresh rock } \\
\text { Fresh rock }\end{array}$ & 0.027 & 36.6 & 0.8 & 1 & 3 & 0.332 \\
Waste material & 0.025 & 35 & 0.24 & 0.05 & 0.05 & 0.3 \\
\hline
\end{tabular}




\section{Simulation Result and Analysis}

There were in total 48 simulations that have been run to investigate the shear stress behavior on pit-slope for differences scenarios of pit-slope depth, IWD height and buffer zone length. The simulation results are summarized in Table 2.

Case 1: Effect of IWD on shear strain behavior on pit-slope.

In this case, the study was done based on simulation result for model of 240-m-deep pit-slope which illustrates actual pit-slope depth of the studied mine. The simulation was done for two conditions i.e. without and with IWD at top of the pit-slope. The simulation results can be seen in Figure 6(a) which shows a pit-slope without IWD, and Figure 6(b) which shows a model with 50-m-high IWD without buffer zone. Figure 6(a) shows that the SRF of the model of 240$\mathrm{m}$-deep pit-slope without IWD is 1.68 . While, SRF of the model of 240 -m-deep pit-slope with 50-m-high IWD is 1.33 (Figure 6(b)). It is seen in the figures that, the yield zone of Figure 6(b) is larger than that of Figure 6(a). It proves that shear stress imposed on the pit-slope increases by IWD. The largest increase in yield zone is found in toe of pit-slope and oxidation zone due to increasing tensile strain and shear stress in these zones, respectively.

Case 2: Effect of increasing pit-slope depth on shear stress behavior.

Table 2 shows that when the pit-slope depth increases from 240 to $440-\mathrm{m}$-deep, the SRF reduces from 1.68 to 1.36 . This condition is evidently visualized by Figure 6(a) and Figure 7. These figures show that the yield zone of 440-m-deep pit-slope without IWD (Figure 7) is larger than that of 420-m-deep pit-slope without IWD (Figure 6(a)). In this case, the increase in shear stress is a response of the increase in gravity load due to the increase in pit-slope depth. The increase

Table 2. Summary of SRF value.

\begin{tabular}{ccccccc}
\hline \multirow{2}{*}{$\begin{array}{c}\text { Pit-slope depth, } \\
d_{s}(\mathrm{~m})\end{array}$} & $\begin{array}{c}\text { IWD height, } \\
h_{d}(\mathrm{~m})\end{array}$ & \multicolumn{5}{c}{ Buffer zone length, $I_{b}(\mathrm{~m})$} \\
\cline { 3 - 7 } & 0 & 1.68 & - & - & - & - \\
\hline \multirow{2}{*}{240} & 50 & 1.33 & 1.49 & 1.54 & 1.56 & 1.62 \\
& 100 & 1.14 & 1.31 & 1.41 & 1.48 & 1.54 \\
& 150 & 1.06 & 1.19 & 1.34 & 1.35 & 1.36 \\
\hline \multirow{3}{*}{340} & 0 & 1.46 & - & - & - & - \\
& 50 & 1.22 & 1.26 & 1.33 & 1.36 & 1.42 \\
& 100 & 1.12 & 1.17 & 1.27 & 1.28 & 1.3 \\
& 150 & 0.94 & 1.07 & 1.19 & 1.15 & 1.2 \\
\hline \multirow{2}{*}{440} & 0 & 1.36 & - & - & - & - \\
& 50 & 1.15 & 1.21 & 1.26 & 1.29 & 1.32 \\
& 100 & 1.07 & 1.13 & 1.16 & 1.19 & 1.22 \\
& 150 & 0.87 & 0.9 & 1.12 & 1.15 & 1.19 \\
\hline
\end{tabular}




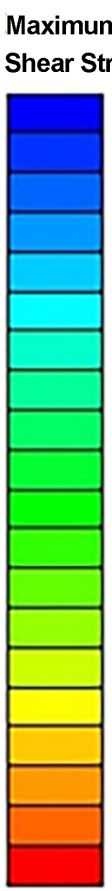

Shear Strain

$0.00 e+000$

$2.00 \mathrm{e}-003$

$4.00 \mathrm{e}-003$

$6.00 \mathrm{e}-003$

$8.00 \mathrm{e}-003$

$1.00 \mathrm{e}-002$

$1.20 \mathrm{e}-002$

$1.40 \mathrm{e}-002$

$1.60 \mathrm{e}-002$

$1.80 \mathrm{e}-002$

$2.00 \mathrm{e}-002$

$2.20 \mathrm{e}-002$

$2.40 \mathrm{e}-002$

$2.60 \mathrm{e}-002$

$2.80 \mathrm{e}-002$

$3.00 \mathrm{e}-002$

$3.20 \mathrm{e}-002$

$3.40 \mathrm{e}-002$

$3.60 \mathrm{e}-002$

$3.80 \mathrm{e}-002$

$4.00 \mathrm{e}-002$

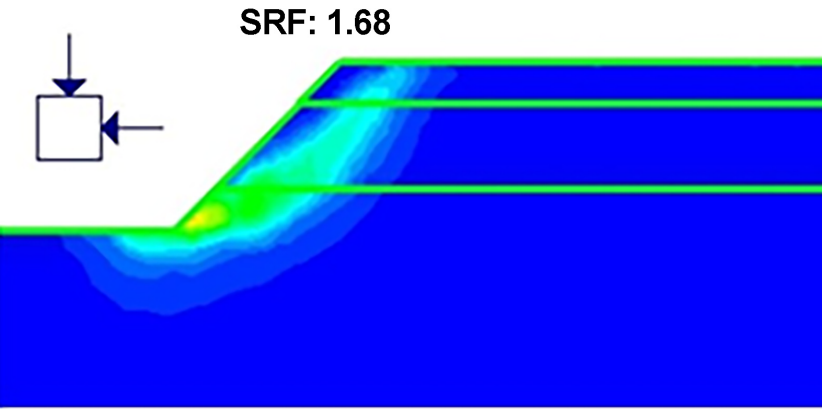

(a) No waste dump

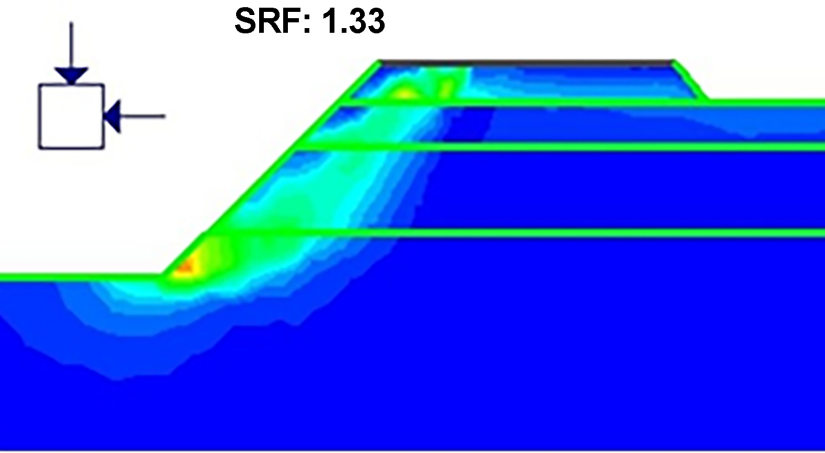

(b) 50-m-high waste dump

Figure 6. Simulation results of 240-m-deep pit-slope model: (a) Without IWD; (b) With 50-m-high IWD.

\section{Maximum}

Shear Strain

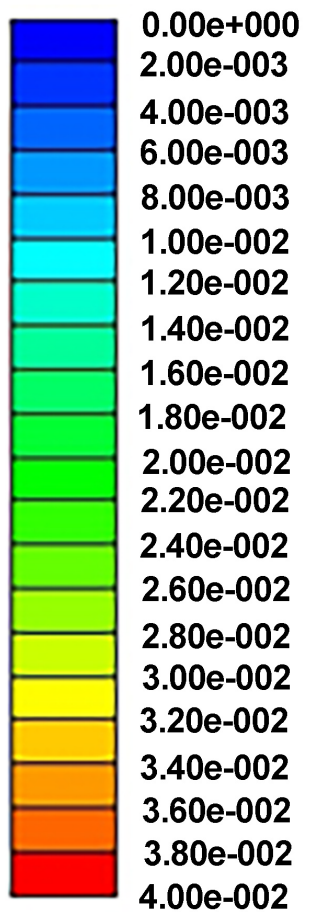

SRF: 1.36

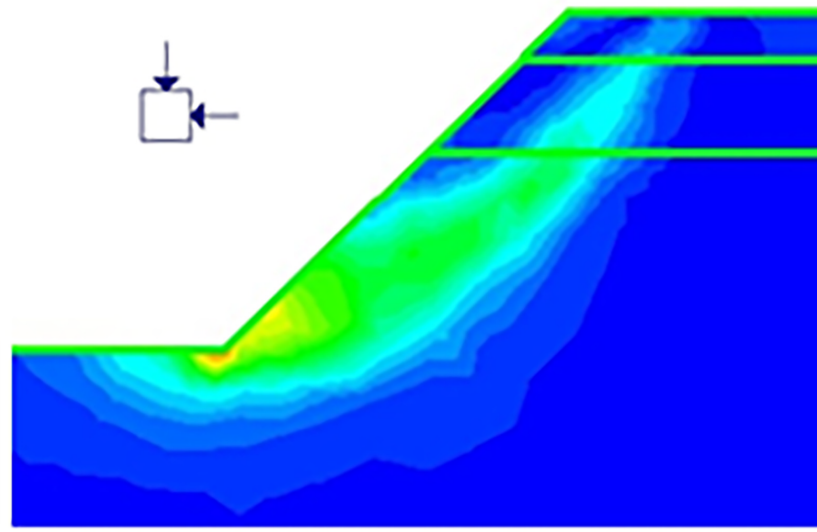

Figure 7. Simulation results of Simulation result of 440-m-deep pit-slope model without IWD. 
in gravity load degrades mobilized cohesion and mobilized friction angle step by step until the slope reaches to a quasi-static state. This situation can lead hazardous condition when an IWD is dumped just next to boundaries of the 440-m-deep pit-slope. This dumping work can trigger the pit-slope more distressed due to increase in IWD-induced shear stress. This cohesion and friction degradation process will drive the slope model to deform until the bond material break. The bond breaks due to shear failure will occur at the toe of the pit-slope. After the gravity load accumulates at toe of the pit-slope, tensile failure will occur at the crack tip. If this tensile failure propagates toward surface, it can bring the slope collapse (Nishimura et al., 2010; Kaneko et al., 1997).

Case 3: Effect of increasing IWD height on shear stress behavior on pit-slope and IWD.

Figure 8(a) and Figure 8(b) show that the yield zone imposed on pit-slope particularly at oxidation zone increases with increasing the IWD height from 50 to $100-\mathrm{m}$-high. The figures show that the SRF weaker from 1.26 which in this study is categorized as critical value to 1.17 which is categorized as unsafe condition. Moreover, based on the simulation result, when the IWD height is 100-m-high, an attention shall be given to stability of the IWD itself. Figure 8(b) shows that high shear stress is concentrated in the toe of IWD. The increase in shear stress at the toe of the IWD may due to very low cohesion of the waste material, and it gives great effects on strength of material stability of the IWD (Aladejare \& Wang, 2017).

Case 4: Effect of buffer zone on shear strain behavior on pit-slope with IWD.

The increase in IWD-induced shear stress on pit-slope can be restrained by introducing buffer zone between IWD and pit-slope. Figure 9(a) to Figure 9(d) show the effect of buffer zone on stability of 440-m-deep pit-slope integrated with 50-m-high IWD. These figures show that the shear stress imposed on pit-slope diminishes with increasing the buffer zone length. Moreover, in a certain buffer zone length, stability of pit-slope can be deemed less relationship with IWD. Figure 9(d) shows almost no yield zone interference between pit-slope and IWD when buffer zone length is $200-\mathrm{m}$-long. This surmise is strengthened by the simulation results that show SRF of 440-m-deep pit-slope integrated with 50-m-high IWD which located at 200-m-long from the boundaries of pit-slope (Figure 9(d)) is almost similar with SRF of 440-m-deep pit-slope without IWD (Figure 7) i.e. 1.32 and 1.36 , respectively.

\section{Discussion}

In this section, the discussion is constructed by numerical evidence i.e. shear stress behavior for different geometry of pit-slope, IWD and buffer zone. The governing configuration is derived for three different pit-slope depths integrated with three IWD heights and five different buffer zone lengths. Figure 10 gives illustration correlation between IWD height and SRF for different depth of pit-slope: three different pit-slope depths (i.e. 240, 340 and 440-m-deep) integrated with 


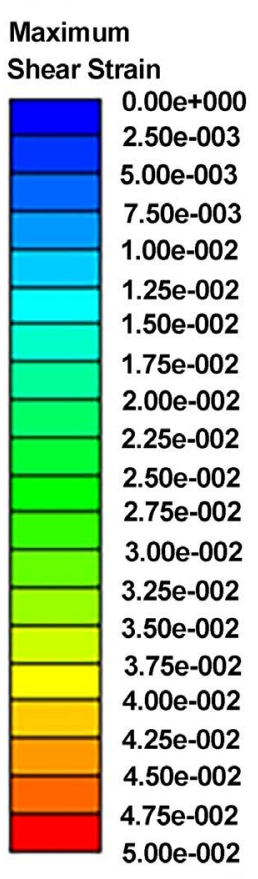

Figure 8. Simulation results of 340-m-deep pit-slope model integrated with 50-m-long buffer zone for different IWD geometry: (a) 50-m-high dump; (b) 100-m-high dump.

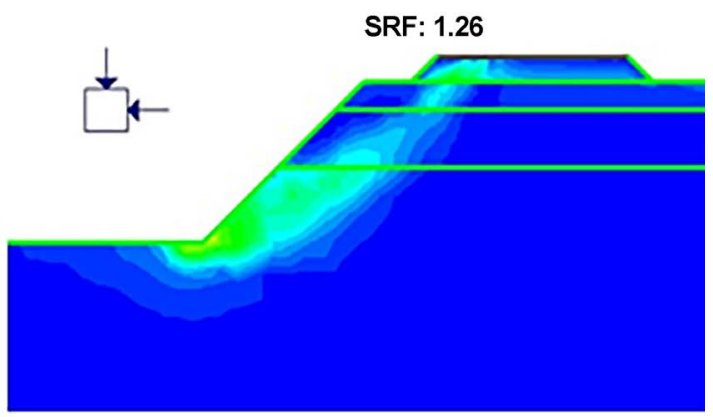

(a) 50-m-high waste dump

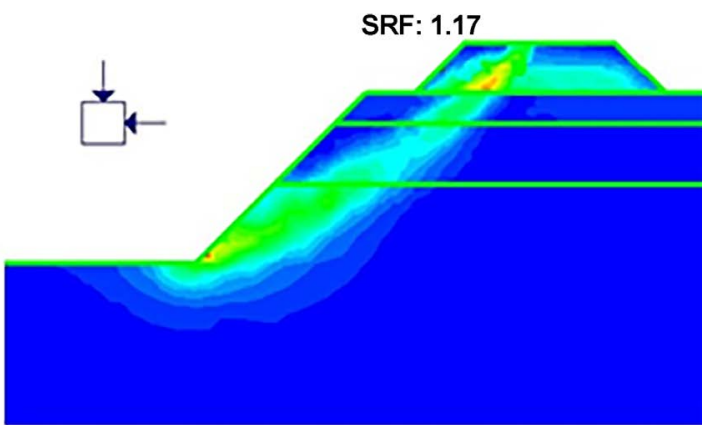

(b) 100-m-high waste dump
Maximum

Shear Strain

\begin{tabular}{|l|}
\hline \\
\hline \\
\hline \\
\hline \\
\hline \\
\hline \\
\hline \\
\hline \\
\hline \\
\hline \\
\hline \\
\hline
\end{tabular}

SRF: 1.21

(3.000003

$7.00 \mathrm{e}-003$

$1.05 \mathrm{e}-003$

$1.40 \mathrm{e}-002$

$1.75 \mathrm{e}-002$

$2.10 \mathrm{e}-002$

$2.45 \mathrm{e}-002$

$2.80 \mathrm{e}-002$

$3.15 \mathrm{e}-002$

$3.50 \mathrm{e}-002$

$3.85 \mathrm{e}-002$

$4.20 \mathrm{e}-002$

$4.55 \mathrm{e}-002$

$4.90 \mathrm{e}-002$

$5.25 \mathrm{e}-002$

$5.60 \mathrm{e}-002$

$5.95 \mathrm{e}-002$

$6.30 \mathrm{e}-002$

$6.65 \mathrm{e}-002$

$7.00 \mathrm{e}-002$

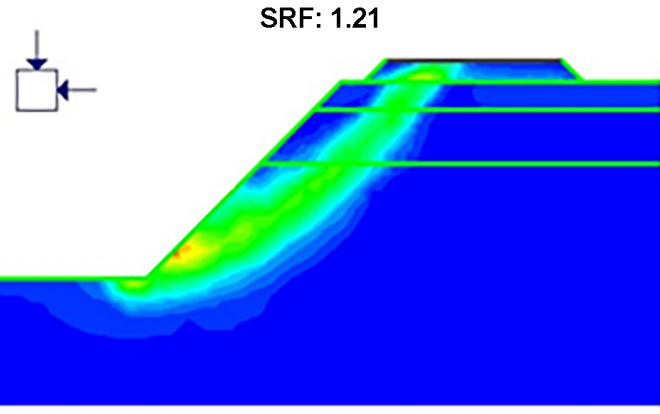

(a) 50-m-long buffer zone

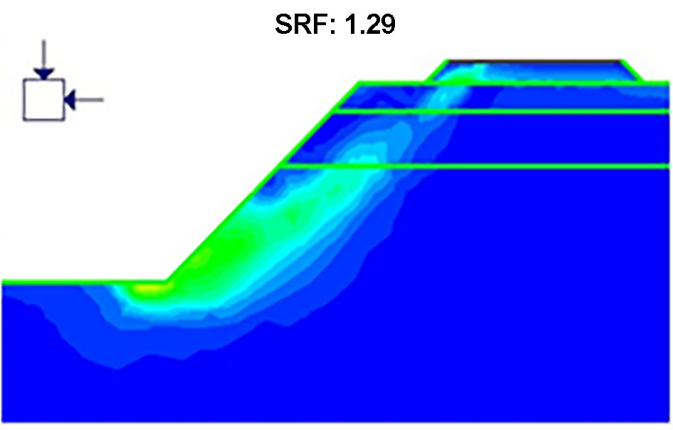

(c) 150-m-long buffer zone

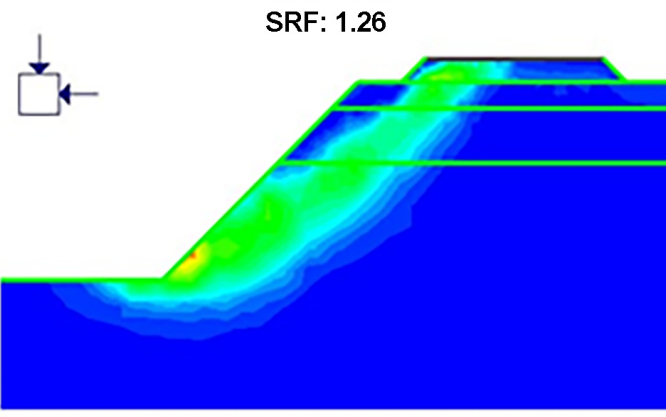

(b) 100-m-long buffer zone

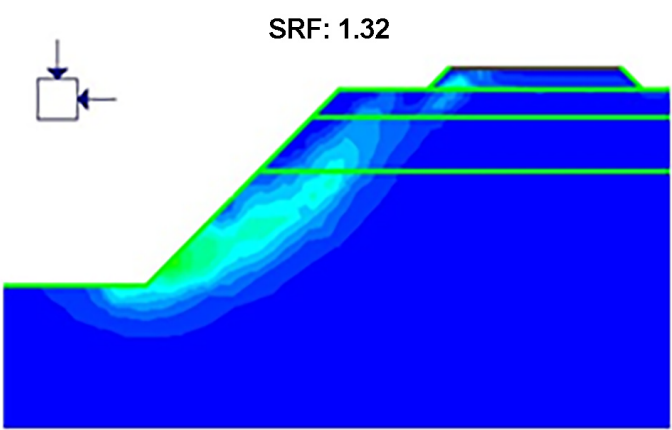

(d) 200-m-long buffer zone

Figure 9. Simulation result of 440-m-deep pit-slope integrated with 50-m-high IWD model for different buffer zone length configurations: (a) 50-m-long buffer zone; (b) 100-m-long buffer zone; (c) 150-m-long buffer zone; (d) 200-m-long buffer zone. 


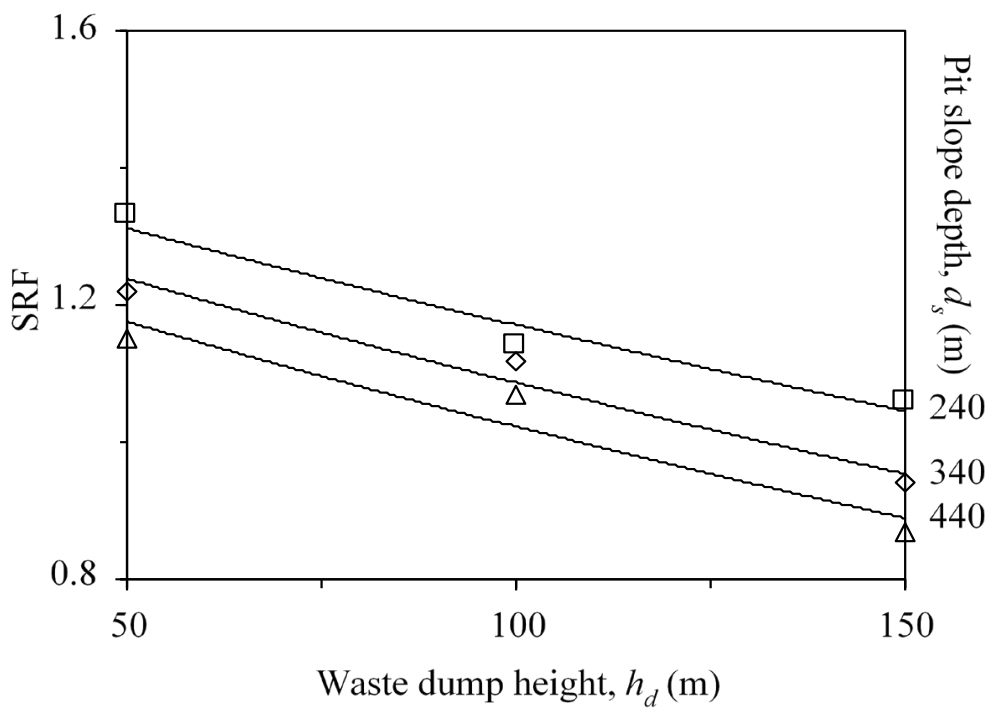

Figure 10. Correlation between SRF and IWD height associated with pit-slope depth for 0-m-long buffer zone.

three IWD heights (i.e. 50, 100, 150-m-high) for 0-m-long buffer zone. The figure shows that the SRF decreases with increasing IWD height. The SRF also decreases with increasing pit-slope depth. A similar characteristic with this correlation as shown in Figure 10 is also found for case of 50, 100, 150 and 200-m-long buffer zone. Based on this correlation's characteristic, the correlation between SRF and IWD height for any depths of pit-slope and lengths of buffer zone can be expressed by equation as follows:

$$
S R F=k \mathrm{e}^{-b h_{d}} .
$$

where, $h_{d}$ is IWD height, and $b$ and $k$ are a constant. Considering to Figure 10, constant $k$ can physically be considered to represent the SRF, which reduces with increasing IWD height, as per degree $b$ of deterioration.

The constants $b$ and $k$ that illustrates correlation between SRF and IWD height for any depths of pit-slope and length of buffer zone are given in Table 3. This table shows that constant $b$ decreases from 0.003 to 0.002 to 0.001 with increasing buffer zone length from 0 to 50 to $100-\mathrm{m}$-long, respectively. However, the $b$ value is constant in 0.001 when the buffer zone length is more than $100-\mathrm{m}$-long. It indicates that constant $b$ is influenced by IWD if the buffer zone is less than 100-m-long from boundaries of the pit-slope. This correlation can be seen in Figure 11. This figure shows a linear correlation with correlation coefficient (-)1 between constant $b$ and buffer zone less than 100-m-long, which indicates a perfect downhill linear correlation. This correlation can be expressed with equation as follows:

$$
b=-2 \times 10^{-5} l_{b}^{\prime}+0.003 .
$$

where $l_{b}^{\prime}$ is buffer zone length in a range of 0 to 100 -m-long.

Constant $k$ which is physically representing SRF looks like controlled by pit-slope depth and buffer zone length. In order to confirm it, constant $k$ is 
Table 3. Summary of constants $b$ and $k$.

\begin{tabular}{|c|c|c|c|c|}
\hline \multirow{2}{*}{$\begin{array}{l}\text { Buffer zone length, } \\
\qquad I_{b}(\mathrm{~m})\end{array}$} & \multirow{2}{*}{$\begin{array}{c}\text { Slope height, } \\
d_{s}(\mathrm{~m})\end{array}$} & \multicolumn{2}{|c|}{ Constant } & \multirow{2}{*}{$\frac{\text { Corr. Coef. }}{R}$} \\
\hline & & $b$ & $k$ & \\
\hline & 240 & 0.002 & 1.4697 & 0.998 \\
\hline \multirow[t]{3}{*}{0} & 340 & 0.003 & 1.4108 & 0.998 \\
\hline & 440 & 0.003 & 1.3522 & 0.996 \\
\hline & 240 & 0.002 & 1.6582 & 1 \\
\hline \multirow[t]{3}{*}{50} & 340 & 0.002 & 1.3708 & 1 \\
\hline & 440 & 0.003 & 1.4407 & 0.995 \\
\hline & 240 & 0.001 & 1.6407 & 0.999 \\
\hline \multirow[t]{3}{*}{100} & 340 & 0.001 & 1.4105 & 1 \\
\hline & 440 & 0.001 & 1.3259 & 0.997 \\
\hline & 240 & 0.001 & 1.688 & 0.999 \\
\hline \multirow[t]{3}{*}{150} & 340 & 0.002 & 1.4905 & 0.999 \\
\hline & 440 & 0.001 & 1.3557 & 0.997 \\
\hline & 240 & 0.002 & 1.7899 & 0.997 \\
\hline \multirow[t]{2}{*}{200} & 340 & 0.002 & 1.5426 & 1 \\
\hline & 440 & 0.001 & 1.3778 & 0.996 \\
\hline
\end{tabular}

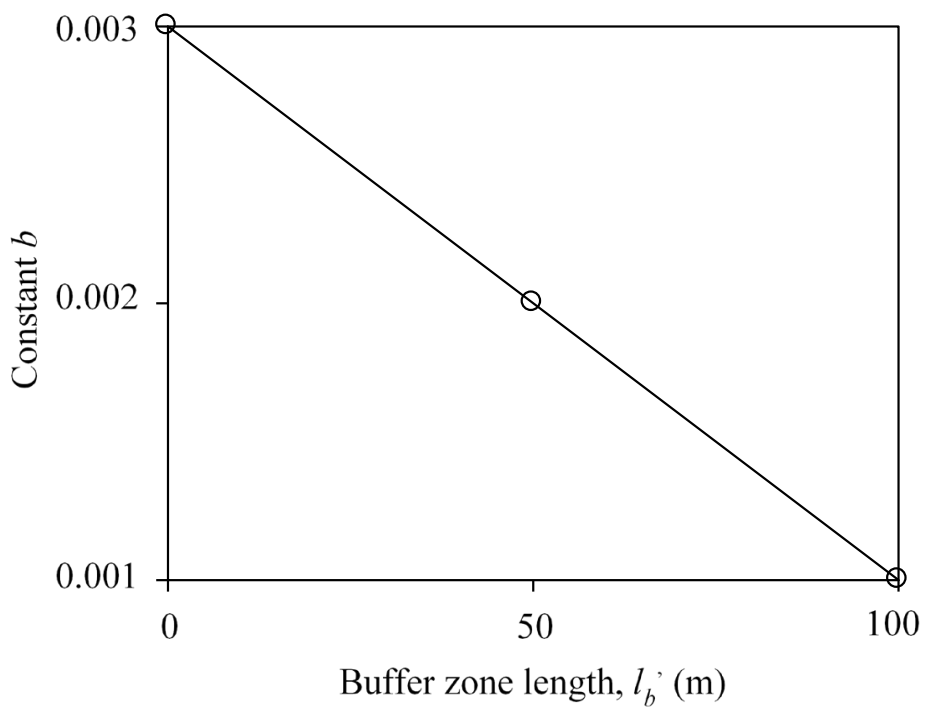

Figure 11. Correlation between constants $b$ and $l_{b}^{\prime}$.

plotted as function of pit-slope depth for any length of buffer zone (i.e. 0, 50, 100, 150, 200-m-long), as shown in Figure 12. It can be seen in this figure that constant $k$ decreases in different degree of decay with increasing pit-slope depth for buffer zone length less than 100 -m-long i.e. 0.0004 to 0.0007 to 0.001 for buffer zone equals to 0,50 and 100-m-long, respectively. For buffer zone length 


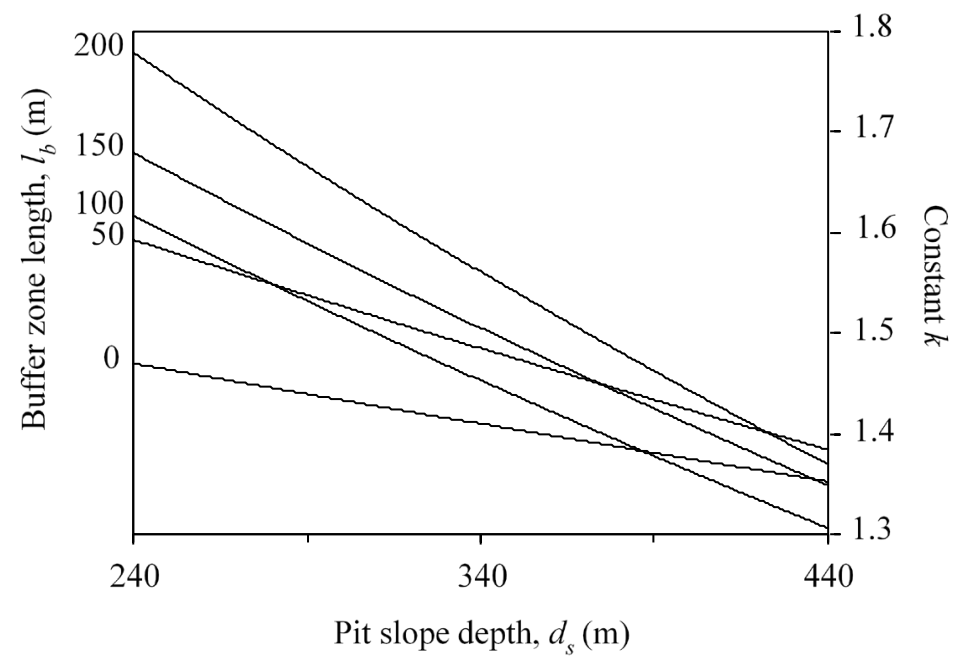

Figure 12. Correlation between constant $k$ and pit-slope depth and buffer zone length.

more than 100-m-long, constant $k$ decays in similar rate of 0.001 . The correlation between $k$ for buffer zone length less than 100-m-long can be expressed in equation as follows:

$$
k=c \mathrm{e}^{-y d_{s}} .
$$

where $d_{s}$ is pit-slope depth, and $y$ and $c$ are a constant. Constants $y$ and $c$ are given in Table 4.

Table 4 shows that constant $y$ is influenced by buffer zone length less than 100-m-long $\left(l_{b}^{\prime}\right)$ and less influenced by buffer zone length more than 100-m-long. This characteristic is in a line with characteristic of constant $b$ which is less effected by a changing of buffer zone when the length is more than 100 -m-long as written in Table 3 . The correlation between buffer zone less than 100-m-long and constant $b$ is illustrated in Figure 13.

Figure 13 shows that the correlation coefficient between buffer zone length less than 100-m-long and constant $y$ is 1 , which indicates a perfect uphill linear relationship. Correlation between constant $y$ and buffer zone length less than 100-m-long can be expressed in equation as follows:

$$
y=6 \times 10^{-6}\left(l_{b}^{\prime}\right)+0.0004 .
$$

Different with constants $b$ and $y$ which is less influenced by buffer zone when the length is more than 100-m-long, the constant $c$ in Equation (7) is certainly influenced by buffer zone without any conditions. Table 4 shows that constant $c$ increases with increasing buffer zone length. This correlation is illustrated in Figure 14. It is seen in this figure that the correlation coefficient of this correlation is very strong i.e. 0.991 . This correlation can be ex-pressed with equation as follows:

$$
c=3.8 \times 10^{-3} l_{b}+1.6595 .
$$

where $I_{b}$ is buffer zone length from 0 to 200 -m-long. 
Table 4. Summary of constants $y$ and $c$ for equation $k=c \mathrm{e}^{-y d_{s}}$.

\begin{tabular}{|c|c|c|c|}
\hline \multirow{2}{*}{$\begin{array}{l}\text { Buffer zone length, } \\
\qquad I(\mathrm{~m})\end{array}$} & \multicolumn{2}{|c|}{ Constant } & \multirow{2}{*}{$\begin{array}{c}\text { Corr. Coef. } \\
R\end{array}$} \\
\hline & $y$ & $c$ & \\
\hline 0 & 0.0004 & 1.6247 & 0.999 \\
\hline 50 & 0.0007 & 1.886 & 0.712 \\
\hline 100 & 0.001 & 2.0873 & 0.972 \\
\hline 150 & 0.001 & 2.1851 & 0.997 \\
\hline 200 & 0.001 & 2.4357 & 0.997 \\
\hline
\end{tabular}

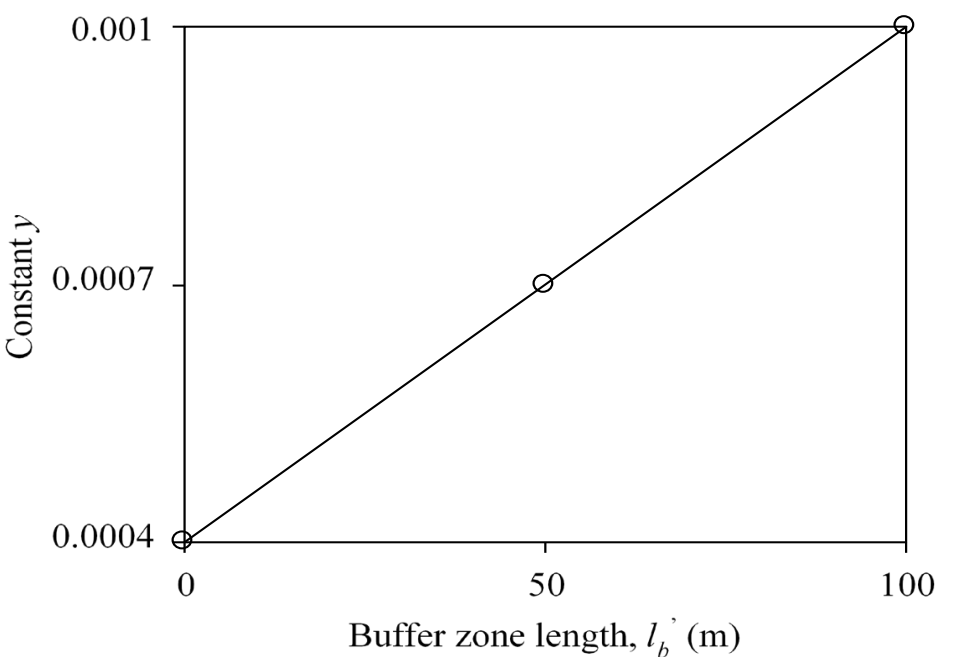

Figure 13. Correlation between constant $y$ and $l_{b}^{\prime}$.

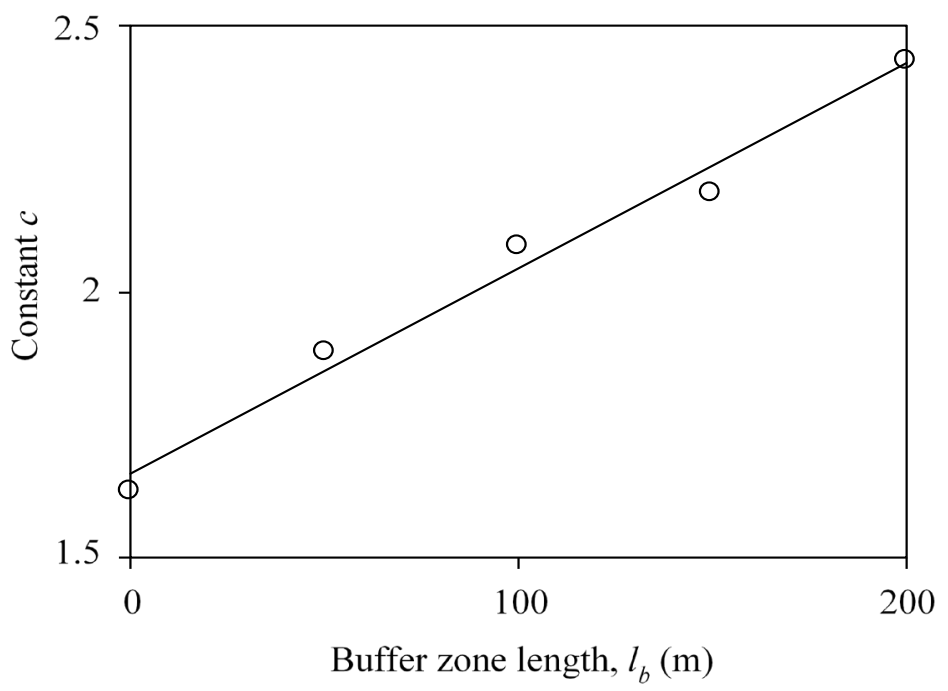

Figure 14. Correlation between constant $c$ and $l_{b}$.

By substituting Equations (8) and (9) to Equation (7) to get constant $k$ and substituting the constant $k$ and Equation (6) to Equation (5), the sensitivity chart of IWD-induced shear stress behavior on a pit-slope under stability level SRF 1.25 was constructed. The sensitivity chart is given in Figure 15. In the sensitivity analysis, 


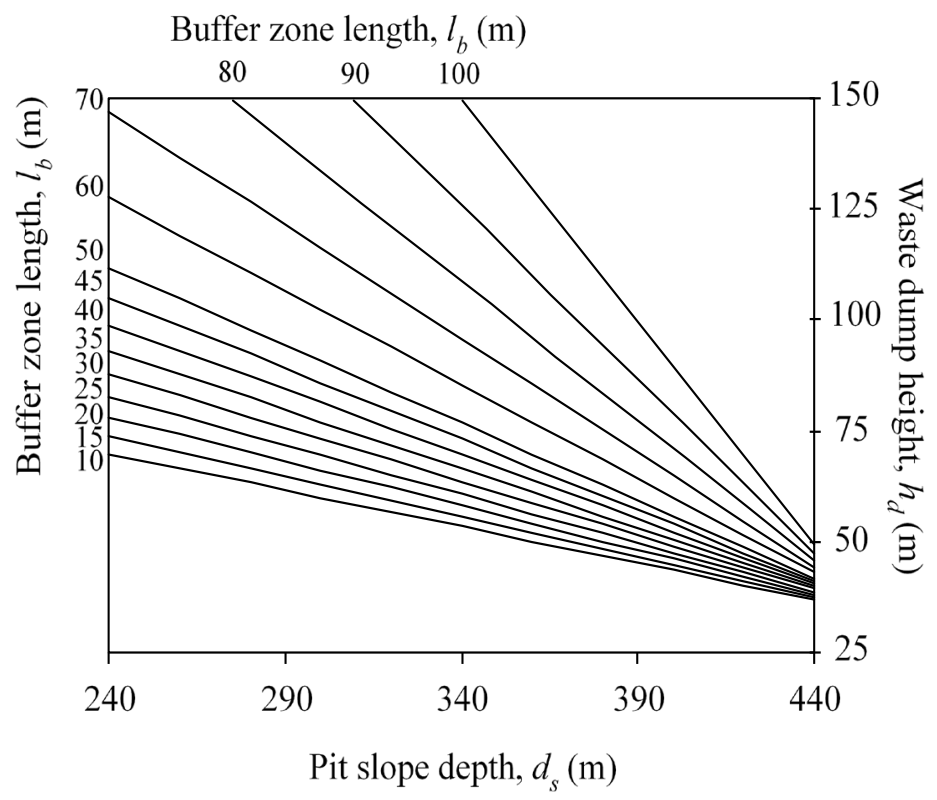

Figure 15. Correlation between safe deep limit of pit-slope, safe high limit of waste dump for difference cases of buffer zone length for SRF 1.25 .

the data which plotted in the graph is for buffer zone length 10 to $100-\mathrm{m}$-long considering to a significant change in SRF under this buffer zone range of length.

It is observed in Figure 15 that safe high limit of IWD decreases with increasing safe deep limit of pit-slope. Moreover, the degree of decay of safe high limit of IWD increases with increasing buffer zone length. This phenomenon makes a convergence form in interrelationship between pit-slope depth, IWD height and buffer zone length. This figure shows that in case of 440-m-deep pit-slope, the safe high limit of IWD for buffer zone length in range of 10 to 100 -m-long is insignificant different i.e. around 37 to $45-\mathrm{m}$-high. It indicates that in case of deep pit-slope, the shear stress on pit-slope is sensitive to increase in IWD height for buffer zone length less than 100-m-long.

Moreover, there are two convergence characteristics in interrelationship between pit-slope depth and IWD height for increasing buffer zone length. A slight convergence is found for case of buffer zone length less than 50-m-long. While a considerable convergence is found for case of buffer zone length more than 50-m-long. A slight convergence indicates a considerable sensitivity of increasing IWD height on safe deep limit of pit-slope. In this case, buffer zone is considered not effective to control IWD-induced shear strain imposed on pit-slope. It may due to the area within 50-m-long from the boundaries of pit-slope is zone of potential failure which is sensitive responsive and responsiveness to external force. While, a considerable convergence indicates less shear stress behavior on pit-slope due to substantial effectivity of buffer zone to control IWD-induced shear strain. 


\section{Conclusion}

Internal waste dump (IWD) within boundaries of pit-slope is one of solutions to cut the waste material hauling cost owing to location of IWD close to the pit. However, this method also can introduce a serious problem on stability of the pit-slope considering area within the boundaries of pit-slope is a zone that is easy to deform. Therefore, it is paramount to investigate shear stress behavior on pit-slope with IWD case to prevent the slope failures. In this study, IWD-induced shear strain that imposed on pit-slope is simulated by using Finite Element Method (FEM) with strength reduction approach.

Simulation result shows that shear stress on pit-slope changes with changing geometry of pit-slope depth, present of IWD on top of pit-slope as well as IWD height, and buffer zone length. The change occurs particularly at toe region of pit-slope. If this induced-shear stress is not controlled, tensile failure will occur at crack tip accordingly. If this tensile failure propagates toward surface, the slope is very possible to collapse. Thus, control shear stress imposed on pit-slope is key on implementation of IWD.

Simulation results show that the induced-shear stress increases with increasing pit-slope depth and increasing IWD depth but decreases with increasing buffer zone length. This study exhibits the shear strength dependency of shear stress by sensitivity analysis. The sensitivity analysis is done based on performance of geometrical combinations analysis between pit-slope depth, IWD height and buffer zone length by means of numerical simulation.

According to the sensitivity analysis, which is concluded from 48 simulations, safe deep limit of pit-slope is considerably influenced by IWD height for buffer zone length less than 100-m-long. The shear stress on this case of pit-slope seems changed dramatically with increasing IWD height. It may due to the area within less than 100-m-long buffer zone is potential failure zone which largely distressed. Considering to these analyses results, a geo-technical engineering can have a predictive capability for design of IWD, and that predictive capability can only be achieved. Moreover, considering this study was conducted at low rainfall infiltration condition, further analysis of saturated stability analyses should be conducted to predict shear stress behavior on more critical conditions.

\section{Acknowledgements}

The authors express their gratitude to Mining Research and Design Center, Mongolian University of Science and Technology for providing the field data. The paper is the effect of the scientific project between Mongolian University of Science and Technology and Kyushu University.

\section{Conflicts of Interest}

The authors declare no conflicts of interest regarding the publication of this paper. 


\section{References}

Aladejare, A. E., \& Wang, Y. (2017). Evaluation of Rock Property Variability. Georisk: Assessment and Management of Risk for Engineered Systems and Geohazards, 11, 22-41. https://doi.org/10.1080/17499518.2016.1207784

Calder, P. (1977). Ch. 7: Perimeter Blasting, Pit Slope Manual. CANMET Report 77-14.

Cho, Y. C., \& Song, Y. S. (2014). Deformation Measurements and a Stability Analysis of the Slope at a Coal Mine Waste Dump. Ecological Engineering, 68, 189-199. https://doi.org/10.1016/j.ecoleng.2014.03.005

Hammah, R. E., Yacoub, T. E., Corkum, B. C., \& Curran, J. H. (2005). The Shear Strength Reduction Method for the Generalized Hoek-Brown Criterion. In Proceedings of 40th U.S. Symposium on Rock Mechanics (ARMA/USRMS 05-810). Anchorage: Curran Associates, Inc.

Hustrulid, W. A., Kuchta, M., \& Martin, R. K. (2013). Open Pit Mine Planning \& Design (3rd ed.). Leiden: CRC Press.

Itasca (2004). Website of UDEC and FLAC 3D, Itasca Consulting Group, Itasca, Minneapolis, $M N$. http://www.itascacg.com

Jimenez-Rodriguez, R., \& Sitar, N. (2007). Rock Wedge Stability Analysis Using System Reliability Methods. Rock Mechanics and Rock Engineering, 40, 419-427. https://doi.org/10.1007/s00603-005-0088-x

Jimenez-Rodriguez, R., Sitar, N., \& Chacon, J. (2006). System Reliability Approach to Rock Slope Stability. International Journal of Rock Mechanics and Mining Sciences, 43, 847-859. https://doi.org/10.1016/j.ijrmms.2005.11.011

Kaneko, K., Otani, J., Noguchi, Y., \& Togashiki, N. (1997). Rock Fracture Mechanism Analysis of Slope Failure. In Proceedings of International Symposium on Deformation and Progressive Failure in Geomechanics (pp. 671-676). New York: Pergamon.

Khandelwal, M., \& Singh, T. N. (2009). Prediction of Blast-Induced Ground Vibration Using Artificial Neural Network. International Journal of Rock Mechanics and Mineral Science, 46, 1214-1222. https://doi.org/10.1016/j.ijrmms.2009.03.004

Li, D. Q., Chen, Y., Lu, W., \& Zhou, C. B. (2011). Stochastic Response Surface Method for Reliability Analysis of Rock Slopes Involving Correlated Non-Normal Variables. Computers and Geotechnics, 38, 58-68. https://doi.org/10.1016/j.compgeo.2010.10.006

Low, B. K. (2007). Reliability Analysis of Rock Slopes Involving Correlated Non-Normal. International Journal of Rock Mechanics and Mining Sciences, 44, 922-935. https://doi.org/10.1016/j.ijrmms.2007.02.008

Nishimura, T., Tsujino, K., \& Fukuda, T. (2010). Effects of Model Parameters in DEM on Slope Failure Simulation. In Zhao, Labiouse, Dudt, \& Mathier (Eds.), Rock Mechanics in Civil and Environmental Engineering (pp. 551-554). London: Taylor \& Francis Group.

Persson, P. A., Holmberg, R., \& Lee, J. (1994). Rock Blasting and Explosives Engineering. London: CRC Press.

Rockfield (2001). Website of Rockfield Software, ELFEN, UK. http://www.rockfield.co.uk/elfen

Rocscience (2005). Phase2 2D Elasto-Plastic Finite Element Stress Analysis Program for Underground or Surface Excavations in Rock or Soil. Toronto: Rocscience.

Scott, M. D., Lo, R. C., \& Thavaraj, T. (2007). Use of Instrumentation to Safeguard Stability of a Tailing Dam. In Proceedings of 7th International Symposium on Field Measurements in Geomechanics (pp. 692-704). Boston. https://doi.org/10.1061/40940(307)56

Wesseloo, J., \& Read, J. (2009). Guidelines for Open Pit Slope Design. In J. Read, \& P. Stacey (Eds.), Acceptance Criteria (pp. 221-236). Collingwood: CRC Press. 